\title{
The Effect of a We6Quest-Based Program on Developing the EFL Listening and Speaking Skills of Secondary Stage Students
}

\section{Mr. Ahmed Saad El-Sayed Salem, Prof.Aly A. Qoura, Ass. Prof.Mervat S. Alhadidy}

Mansoura University, Faculty of Education, Department of Curriculum \& Instruction

\section{Abstract}

he study aimed at investigating the effect of a WebQuest-Based
Program (WQBP) on developing the EFL listening and speaking
skills General Secondary School. The participants of the study
were Forty (40) Second Year General Secondary School Students from Temay AlAmdid General Secondary School, Dakahliya, Egypt. The study adopted the quasi-experimental research design to proceed the experiment. So, there were two groups: an experimental group $(n=20)$ and a control one $(n=20)$. To collect data, the researcher used multiple instruments: a listening sub-skills checklist, a speaking sub-skills checklist, a computer and Internet Skills Survey to choose the sample, two pre posttests of listening and speaking, a speaking assessment rubric, and a reflection log for students to evaluate each webquest of the program. The researcher taught both groups: the experimental group was taught through the webquest based program (WQP) while the control group was taught through the traditional way of teaching. The results of the study revealed the following: there were statistically significant differences at the level $(0.05)$ between the mean scores of the participants of the experimental group and those of the control group on the post application of the listening test in favor of the experimental group;there were statistically significant differences at the level (0.05) between the mean scores of the participants of the experimental group and those of the control group on the post application of the speaking test in favor of the experimental group;there were statistically significant differences between the mean scores of the experimental group members on the pre and post application of the pre post-test of the listening test in favor of the post application; there were statistically significant differences between the mean scores of the experimental group members on the pre and post application of the pre post-test of the speaking test in favor of the post application; Hence, the effect size of the webquest program was found to be high in enhancing and developing the listening and speaking skills of the secondary school students. The study recommends using the webquest as a technique in teaching EFL skills and as a training approach in professional development programs of EFL teachers.

Key Words: Webquest, listening, speaking, constructivism, blended learning, EFL 


\section{Introduction:}

Listening is the start of learning a language. Hence, it should be developed and taught thoroughly especially in an early stage of learning a language. Despite this, it has been neglected for so long. In addition, it is not surprising that many educators give little attention to what listening is, how it works, or how it can be developed in others because listening is a challenging skill for both EFL learners to acquire and for EFL instructors to teach (Field 2008; Hamouda, 2013; Siegel, 2014). This is because most people develop their L1 listening abilities seemingly without effort or attention and its momentary nature. Hence, learners often feel overwhelmed by the speed and intangible nature of spoken language. It comes at them rapidly and they typically only have one chance to listen unless they ask for repetition or clarification, which can lead to a loss of face in some contexts. Language students may also be frustrated that there are no rules to memorize that will automatically lead to listening success. Indeed, L2 learners face an big challenge in learning to listen in their new language (Siegel, 2014).

Speaking is the means through which learners can communicate with others to achieve certain goals or to express their opinions, intentions, hopes and viewpoints. In addition, people who know a language are referred to as 'speakers' of that language. Furthermore, in almost any setting, speaking is the most frequently used language skill as listening. As Rivers (1981) argues, speaking is used twice as much as reading and writing in our communication. So, it is a very important skill to boost in our schools.

Speaking is closely related to listening as two interrelated ways of accomplishing communication. Every speaker is simultaneously a listener and every listener is at least potentially a speaker. Also, spoken discourse is always compared to written discourse (Oprandy, 1994: 153). Each discourse has its own characteristics. Both skills are twisted together in all situations. 
It is clear that both skills are so important to develop inside our EFL classrooms. So, a lot of researches have been done to develop them. Despite this, both skills have been neglected for so long in teaching as mentioned (Oxford, 1993; AbdelAl, 2002; Yousif, 2006). Therefore, students still have poor listening and speaking skills (Siegel, 2014) . Hence, it is important to seek a new path to overcome this problem.

The Internet and the world wide web play a crucial role in everyday life, education in general and TEFL in particular. This impact and influence can be best described by Bill Gates's statement: information at your fingertips (Hsiao et al, 2012). Due to this role, the researcher decided to use one of the web tools to teach listening and speaking to secondary stage students. This tool is the webquest.

The concept of WebQuest was developed in 1995 by Bernie Dodge and Tom March as an innovative way for students to learn using available sources through technology. The Term 'WebQuest' is a compound word that comprises two words: 'Web' which means the world wide web in its three phases: web 1.0 to its latest phase web 3.0 as the main source for information, and 'Quest' which means 'a questions, an inquiry' which means looking for information using different resources and ways.

\section{Review of Literature:}

\section{Listening Skills:}

Listening plays an important role in communication as it is said that, of the total time spent on communicating, listening takes up 40-50\%; speaking, 25-30\%; reading, 11-16\%; and writing, about $9 \%$. Listening is the primary means by which incoming ideas and information are taken in. On the other hand, it has been noted that students from kindergarten through high school were expected to listen 65-90 percent of the time... Listening is the most frequently used language skill in the classroom. Both instructors and students acknowledge the importance of listening comprehension for success in academic settings. Numerous studies indicated that efficient listening skills 
were more important than reading skills as a factor contributing to academic success. Nevertheless, it is evident that listening is more important for the lives of students since listening is used as a primary medium of learning at all stages of education (Hamouda, 2013). In addition, instructors and researchers alike have asserted that students who are effective listeners during class are better students than those who listen less effectively in the classroom (Beall et al, 2008: 126).

Despite the importance of listening and the rewards effective listening can bring to the second or foreign language learning process, it has been neglected until the last few decades. Listening was not broadly acknowledged as a skill that needs to be developed in its own right or to be taught explicitly (see Oxford, 1993; AbdelAl, 2002; Yousif, 2006).

The neglect of the listening skill was accompanied with an ongoing debate about which of the four language skills (speaking, listening, reading, and writing) is the most crucial for the learning and acquisition of a second language. However, past research has thus far revealed that a large proportion of the L2 research findings indicates that listening is the most important skill for language learning because it is the most widely used language skill in normal daily life (Rost, 2002- cited in Hamouda, 2013: 113), and it develops faster than the three other language skills, which in turn suggests that it can facilitate the emergence of the other language skills (Oxford, 1993- cited in Hamouda, 2013: 113).

Listening, for many EFL/ESL Learners, is the thing they feel most frustrated with. One the one hand, they can't control the speed of speech and they tend to have difficulties decoding sounds that don't exist in their mother tongue. On the other hand, even when they hear sounds correctly, oftentimes they have interpretation problems due to a lack of vocabulary (Wei, 2006; Beall et al, 2008).

Perhaps the most important reason for such recognition stems from the great problems listening poses for large numbers 
of English language students. These problems are by and large due to the fact that listening is the skill that makes the heaviest processing demands for second/foreign language. This is because students must store information at the same time as they are working to understand it (AbdelAl, 2002:3).

Nevertheless, teaching Listening has already become one of the main goals of teaching English at the secondary stage in Egypt (Directives for General Secondary School Teachers, 20132014). The learning objectives of the second year secondary, in terms of Listening skills, as determined by the Ministry of Education directives and the students' syllabus (Stannard, 2009) are as follows:

\section{Students should learn to:}

1. respond to and follow instructions in different language modes.

2. listen to a variety of native speakers and identify topics.

3. detect attitude and meaning from tone, intonation and gesture of speakers.

4. follow speech in response to one's own utterance.

5 . extract meaning of situational dialogues.

6. extract meaning of topic in connected speech.

7. understand a wide range of question forms.

8. respond to formal and informal utterances.

9. follow discussion on familiar topics.

10. Extract information from various types of discourse.

In principle, listening is now recognized as a skill that can no longer be neglected or superficially treated, or even be left to develop by osmosis (AbdelAl, 2002; Hamouda, 2013). This position has been replaced by an active interest in the role of powerful theories of the nature of language comprehension, and by the inclusion of carefully developed listening courses in many ESL programs. Some applied linguists go so far as to argue that listening comprehension is at the core of second language acquisition and therefore demands a much greater prominence 
in language teaching (Barani, 2011). However, schools still pay attention to English grammar, reading and vocabulary. Listening and speaking are not parts of teachers' agenda. Most teachers take it for granted that it will develop naturally within the process of language learning. In addition, as Hamouda (2013: 114) states, incompetence in listening is easy to hide through nodding and shaking of the head, which may give the impression of understanding, even there is none. Moreover, teachers in the classroom seem to test, not to teach listening. Meanwhile, students seem to learn listening, not listening comprehension. As a result, it remains the most neglected and the least understood aspect of language teaching (AbdelAl, 2002; Hamouda, 2012; Hamouda, 2013: 115) even if it is put into the objectives of the school curriculum. Students may learn better if they have become self-regulated learners. Such relation between listening and self-regulation has been investigated by Fatemi et al (2014) and Latifi et al (2014) who confirmed better results in listening if it was taught according to a self-regulated approach such as the webquest.

\section{Speaking Skills:}

On the other hand, we have the speaking skill which is the means through which learners can communicate with others to achieve certain goals or to express their opinions, intentions, hopes and viewpoints. In addition, people who know a language are referred to as 'speakers' of that language. Furthermore, in almost any setting, speaking is the most frequently used language skill. Speaking has usually been compared to writing, both being considered "productive skills", as opposed to the "receptive skills" of reading and listening. Speaking also is closely related to listening as two interrelated ways of accomplishing communication. Every speaker is simultaneously a listener and every listener is at least potentially a speaker (Torky, 2006: 14).

Speaking skill has many skills (sub-skills/macro skills) underlying it. Florez (1999) highlights them as follows:

1. using grammar structures accurately. 
2. assessing characteristics of the target audience, including sharded knowledge, status and power relations, or differences in perspectives.

3. Selecting vocabulary that is understandable and appropriate for the audience, the topic being discussed, and the setting in which the speech act occurs.

4. applying strategies to enhance comprehensibility, such as emphasizing key words, rephrasing, or checking for listener's comprehension; and Paying attention to the success of the interaction and adjusting components of speech such as vocabulary, rate of speech, and complexity of grammar structures to maximize listener's comprehension and involvement.

In addition, Nunan, (2003- cited in Solcova, 2011: 18) says that teaching speaking means teaching learners to: Produce the English speech sounds and sound patterns; Use word and sentence stress, intonation patterns and the rhythm of the second language; Select appropriate words and sentences according to the proper social setting, audience, situation and subject matter; Organize their thoughts in a meaningful and logical sequence; Use language as a means of expressing values and judgments; and Use the language quickly and confidently with few unnatural pauses, which is called as fluency.

Therefore, getting teenagers to use and/or speak in English in class can provide a considerable challenge to most teachers. This might be due to peer-pressure, lack of motivation and lack of support. There is also a lack of an authentic English language environment for English oral communication. Second, the prevailing pedagogy for English learning emphasizes examinations as a primary method of assessment, focusing on vocabulary, grammar, reading, and comprehension quizzes. As a result, teacher-centered and rote instructional methods often provide little instructive feedback to students and tend to emphasize literacy skills over oral communication. Third, there is considerable variance in English proficiency among students, 
creating an inequality of opportunities for engaging in classroom learning and difficulties for many students due to a mismatch between their abilities and the course content (Yang et al, 2013).

Concerning the position of Speaking Skill in the Egyptian syllabus, the learning objectives of the second-year secondary determined by the Ministry of Education directives are as follows:

\section{Students should learn to:}

1. Initiate exchanges, responding appropriately .

2. Express a range of functions to satisfy social and future needs .

3. Form a range of questions;

4. Present full autobiographical details.

5. Seek such details from others.

6. Retell events in temporal sequence.

7. Construct novel utterances from grammatical knowledge.

8. Give a short presentation on familiar topics.

9. Express ideas on everyday topics; and Reformulate in different linguistic forms.

Overall, the Hello! Series that is being taught to General Secondary Stage Students uses a standards-based communicative approach and methodology for teaching and learning English. The series aims at fulfilling the standards set out in the 2003 Egyptian Ministry of Education Standards Document, which focuses on communication as a main domain for TEFL. According to the document, "students must use English for social purposes. They need to socialize with peers and teachers, and use English for their joyment ...the focus of language instruction is on functional, communicative English and all the four skills are emphasized"(Abdelatif, 2012, p. 79). Nevertheless, the final exams of English in secondary (and preparatory) schools always test the students' abilities in grammar, vocabulary, reading comprehension, pragmatics, paragraph or letter writing. These exams, however, completely 
neglect students' listening and speaking skills "(Abdelatif, 2012, p. 80).

\section{The Internet and language Learning:}

For these challenges mentioned before, a myriad of teaching methods have been used to teach Listening and Speaking Skills. However, students in secondary schools still suffer from inadequacy of such methods to teach them to listen or speak in the TL. Therefore, it is impossible to deny the impact that technology has had on our lives today, especially the Internet. The Internet, which has been with us for long, has pervaded almost every orifice of modern society. It transcends cultural, physical and spatial borders; it encompasses developed and developing worlds; having an e-mail address or website has become as commonplace as having a telephone and now ELT practitioners are experimenting with the use of blogs and wikis in their teaching contexts. We use it to communicate with each other on a daily, hourly or instantaneous basis; we turn to it to learn more about issues that concern us; we can travel vicariously to the farthest corners of the world in a flash; we play games to entertain ourselves, download music and videos, and do our banking. Schools, as the prototypes of the communities that we live in, must obviously provide an education that not only embraces the Internet but also equips our students with the ability to use it (or whatever information technology advances it will lead to in the future) wisely, productively and for the benefit of society (Sen \& Nufeed, 2006).

Considering the effect the Internet has had on everyday life, it would be unwise to keep our doors closed to the use of informational technology in our classrooms and not equip our learners with the skills they need to survive in the real world. This is perhaps the single most compelling reason which drives many educators to try integrating informational technology into the classroom; we perceive the need to provide a rational link between 'education' in our schools and the contribution to society that students will make after graduation. There are plenty of alternatives for teachers who are willing to experiment 
and incorporate informational technology in their classroom teaching, both as an instructional aid and as a tool to facilitate learning (Sen \& Nufeed, 2006). One of these tools is the WebQuest.

\section{WebQuest:}

Dodge (1997) defines the WebQuest as "an inquiryoriented activity in which some or all of the information that learners interact with come from resources on the Internet." WebQuest activities are heavily based on the constructivist point of view of language learning: constructivism is a learner-centered educational theory that contends that to learn anything, each learner must construct his or her understanding by trying new information to prior experiences" (Henson, 2003: cited in McCullers, 2005)

The constructivist view of learning places the students in the commanding position, determining which direction and how the learning will take place based on their individual interpretation of what they see, hear or do in relation to what they already know. WebQuests are a form of application that routes the student toward his/her optimal learning environment.

Dodge (1997) levels the intensity of a WebQuest into two basic types: a short term WebQuests and Long Term WebQuests. The short term WebQuests, taking approximately one to three class periods, has the goal of knowledge acquisition and integration of the newly learned materials. The long term WebQuests, lasting between one week and a month, allows the learner to analyze knowledge, transform it in some manner, and demonstrate an understanding of the material by displaying a creation where others may respond after viewing.

WebQuest is "an inquiry-based teaching tool, in which students of all ages and levels participate in an authentic task that use predesigned, predefined Internet resources, although other print resources can be used". Learners will put the focus on gathering, summarizing, synthesizing, and evaluating the information within clearly defined parameters in order to 
accomplish an authentic task set by the instructor. WebQuests take a problem-solving approach and exhibits a clear structure that guides the learning processes and interactions (Dodge, 2001). Dodge (1997) states that WebQuests should contain at least the following parts:

1. An introduction that sets the stage and provides some background information.

2. A task that is doable and interesting.

3. A set of information sources needed to complete the task. Many (though not necessarily all) of the resources are embedded in the WebQuest document itself as anchors pointing to information on the World Wide Web. Information sources might include web documents, experts available via e-mail or real-time conferencing, searchable databases on the net, and books and other documents physically available in the learner's setting. Because pointers to resources are included, the learner is not left to wander through web space completely adrift.

4. A description of the process the learners should go through in accomplishing the task. The process should be broken out into clearly described steps.

5. Some guidance on how to organize the information acquired. This can take the form of guiding questions, or directions to complete organizational frameworks such as timelines, concept maps, or cause-and-effect diagrams.

6. A conclusion that brings closure to the quest, reminds the learners about what they've learned, and perhaps encourages them to extend the experience into other domains.

Concerning using webquest in language learning, it has been proved to be effective in enhancing language skills especially reading and writing. Laborda, (2010) lists the advantages of using WebQuests in language learning. First, it provides opportunities for lexical and language use input through reading that can be used to construct ideas and 
expressions either by immediate transfer or reinforcement of previously-learned language. Second, it provides opportunities for experiential learning because the students seek information in a significant way of constructing meaning and to develop higher level thinking skills. Third, it involves written and oral language; this language triggers oral development as students learn from the reading input as well as from their partners. This reading input promotes inner speech that is later experienced in oral interaction with other students. Fourth, it provides teachers with an instructional framework to create meaningful online learning activities (Zheng et al, 2008). Fifth, it promotes social interaction as the students need to communicate their findings in a realistic way. Moreover, it allows the contextualization of language learning. If students learn vocabulary in context, they tend to learn it better because the vocabulary becomes an active part of what they really need to know (Laborda, 2010).

With WebQuests students can integrate their computer skills for Target Language oral communication development through cooperation with peers during devising a WebQuest as well as presenting it. WebQuests encourage cooperative learning. Therefore, it stimulates interactions in the target language. Also, WebQuests provide motivation and encourage critical thinking skills. Learners required not only to restate information they find, but also to transform it in order to achieve a given task.

Due to such characteristics, WebQuests have been applied extensively to various educational environments, and their related variables in addition to the EFL skills. These studies proved that WebQuests can improve logical thinking ability in science education (Cigrik and Ergulm 2010); EFL learning (Siko, 2008); critical thinking skills (Vidoni and Muddux, 2002; Puthikanon, 2009); EFL lexical richness (Valesco, 2012); young learners' achievement (Unal et al, 2012); reading skills development (Tsai, 2005; Shan, 2011; Tuan, 2011; ElKhateeb, 2012); reading and writing skills (Mostafa, 2009; Termsinsawadi, 2011; Alshummaimeri, 2012); as a tool of differentiation (Schweizer \& Kossow, 2007); teachers' attitudes 
and reflections (Perkins \& McKnight, 2005; Noordin et al, 2008); teachers' and students' attitudes (Koçak, 2010) EFL writing skill (Chuo, 2007; Alshummaimeri et al, 2011; Alshummaimeri \& Bamanger, 2013). It has been proved that WebQuests use in various learning environments influences learners' learning performance positively. However, very few studies have investigated the relationship between WebQuests and the speaking skill of EFL (Laborda, 2009; Laborda, 2010). Additionally, no studies have investigated the impact of using WebQuests technique on enhancing the listening skill of EFL learners.

\section{Definition of Terms:}

For the purpose of the study, the following terms are defined:

\section{1- WebQuests}

Dodge (1997) defines the 'WebQuest' as"An inquiryoriented activity in which some or all of the information that learners interact with come from resources on the Internet"

\section{2- Listening comprehension:}

It is an active and complex process which requires learners to receive sounds, attend to relevant sounds, assign meaning and store the message for later use (Hasan \& Levine, 2002).

\section{3-Speaking:}

Solcova (2011) describes speaking as "the process of building and sharing meaning through the use of verbal and nonverbal symbols, in a variety of contexts" (p. 17).

\section{Statement of the Problem}

Based on the previous review of literature, the researcher's long experience in the field of TEFL, and the results of the pilot study, the problem of the study was stated as follows: "Secondary stage students find difficulty in learning listening and speaking skills of English Language.

\section{Purpose of the Study:}

The present study aimed at: 
Identifying the extent to which Secondary School Students master the EFL listening and speaking skills.

1. Promoting the Secondary Stage students' EFL listening and speaking skills,

2. Developing a program based on WebQuests to develop Secondary Stage Students' listening and speaking skills, andMeasuring the effectiveness of the proposed program in developing the listening and speaking skills of Secondary Stage Students.

\section{Research Questions:}

The study aimed to investigate the effect of a WebQuestBased Program (WQBP) on enhancing Secondary School EFL Students' Listening and Speaking Skills Therefore, it will seek to answer the following questions:

1. How far do the Secondary Stage Students master EFL listening and speaking skills required of them?

2. What are the features of a WebQuest-Based Program (WQBP) to improve the EFL listening and speaking skills of secondary stage students?

3. What is the effectiveness of a WebQuest-Based program (WQBP) in developing the EFL listening and speaking skills of secondary stage students?

\section{Research Hypotheses:}

The study aimed at testing the following hypotheses:

1. There would be statistically significant difference at the 0.05 level between the mean scores of the two groups of the experiment on the post administration of the listening test due to the effect of the Proposed WebQuest-Based Program (WQBP) in favour of the experimental group.

2. There would be statistically significant differences at the 0.05 level between the mean scores of the two groups of the experiment on the post administration of the speaking test due to the effect of the Proposed WebQuest-Based Program (WQBP) in favour of the experimental group. 
3. There would be a statistically significant difference at 0.05 level between the mean scores of the experimental group on the pre and post application of the pre posttest of listening in favor of the post application.

4. There would be a statistically significant difference at 0.05 level between the mean scores of the experimental group on the pre and post application of the pre posttest of speaking in favor of the post application.

\section{Significance of the study:}

The present study was significant in a number of ways:

1. Establishing a relationship between webquest as a teaching approach and students' self-regulation and enhancing their listening and speaking skills.

2. Investigating the impact of a webquest-based program on developing listening and speaking skills of EFL general second year secondary school students.

\section{Research Methodology}

\section{Participants and Sampling}

1. The study was conducted in Temai Alamdid General Secondary School,. The participants/sample of the study were be (40) amongst $2^{\text {nd }}$ year students. Students study the English language syllabus entitled, "Hello! English for Secondary Schools, Year Two".

2. The sample was selective. Only students who have computer literacy participated in the study. This was determined by a Computer Skills Questionnaire by the researcher ${ }^{1}$ (CSQ).

1 This is a questionnaire aiming to sort students who are good at using computers and the Internet. It starts with gathering demographics of the students, then, in section one, it seeks student information as to whether students have computers at home or not and what type they are, whether they are connected to the Internet or not, and their experience and attitudes towards computers. Section two gleans information about students' computer skills, i.e. 
3. The experimental group $($ No. $=20)$ received the traditional teaching plus the WebQuest-based Program.

4. The control group (No. $=20$ ) received the traditional teaching only.

\section{Design of the Study}

1. The study adapted the Quasi-experimental design in terms of having two groups one control and one experimental. The sample was selected via the computer and Internet skills questionnaire (see appendix $\mathrm{G}$ ).

2. For more data analysis, the study used both qualitative and quantitative methods. This was decided to get better interpretation of results.

\section{Instruments of the Study}

To collect data, the following instruments were used:

1. The proposed WebQuest-Based Programme (WQBP): The program consisted of eight short-term WebQuests, one WebQuest on each selected unit from the set book for $2^{\text {nd }}$ Year Secondary. The program was uploaded on a website that was prepared by the researcher for the study purpose. The selection of the themes of WebQuests will depend on the rich content of units and up-to-date themes.

2. A Listening Skills Checklist: was prepared by the researcher and submitted to a panel of jury to determine its validity and the appropriateness of the skills needed for Egyptian second year secondary students.

3. A Listening Comprehension Achievement pre-posttest constructed by the researcher,

4. A speaking skills checklist was prepared by the researcher and submitted to a panel of jury to determine its validity

keyboarding skills, file management, word processing and operation systems. Section three seeks information as to skills of using the internet and how to access websites. 
and the appropriateness of the skills needed for Egyptian second year secondary students.

5. A pre-post speaking test to measure the overall speaking proficiency and speaking sub-skills of both the experimental and control groups before and after the treatment; constructed by the researcher.

6. A Computer Skills Questionnaire (CSQ) to measure the students' knowledge about computers and their ability to use the Internet. This questionnaire was prepared in order to select the participants of the study. This questionnaire was prepared by the researcher.

\section{The Experiment:}

The researcher prepared a website for the purpose of the study to upload the WebQuest-Based Program (WQBP) on. This website is www.ahmedphd.com. The researcher taught both groups. The control group was taught using the daily traditional or regular way of teaching through the daily sessions whereas the experimental group was taught using the WQBP on different dates.

The program included eight webquests derived from the topics of the textbook that the participants were studying. The researcher started the experiment with an orientation session to teach the participants how to use the website in addition to getting them identify the mechanism of working on the website.

The webquest lessons followed the steps of webquest components: introduction, task, process, resources, evaluation and conclusion in addition to some learning activities online and offline.

\section{Results:}

The results of the study are shown according to the effect of the independent variable (WebQuest program) on the dependent variables of the study (Listening, Speaking, and Self-regulation). Therefore, all hypotheses verifications are shown in order as follows: 
1. Listening skill hypotheses

2. Speaking skill hypotheses

\section{A- Listening Skills Hypotheses:}

\section{A- Control and experimental group comparison in the post application of tests:}

There are statistically significant differences between the mean scores of the participants of both the experimental and the control group on the post application of the listening pre posttest at the level (0.05) in favor of the experimental group.

To verify this hypothesis, Mann-Whitney Test was used to compare the mean scores of the two groups. The Results are presented in table (1):

Table (1) (Z values and Mann-Whitney Test results of the mean scores on Post application of the listening test)

\begin{tabular}{|c|c|c|c|c|c|c|}
\hline VARIABLES & The group & $\begin{array}{c}\text { N.of } \\
\text { cases }\end{array}$ & $\begin{array}{l}\text { Mean } \\
\text { Rank }\end{array}$ & $\begin{array}{l}\text { Sum of } \\
\text { Ranks }\end{array}$ & Z.Value & Sig. \\
\hline \multirow{2}{*}{$\begin{array}{l}\text { Listening for } \\
\text { specific } \\
\text { information }\end{array}$} & Control & 20 & 12.23 & 244.50 & \multirow{2}{*}{-4.747} & \multirow{2}{*}{$\begin{array}{l}0.05 \\
\text { Sig. }\end{array}$} \\
\hline & Experiment & 20 & 28.78 & 575.50 & & \\
\hline \multirow{2}{*}{$\begin{array}{c}\text { Extracting } \\
\text { information }\end{array}$} & Control & 20 & 12.75 & 255.00 & \multirow{2}{*}{-4.518} & \multirow{2}{*}{$\begin{array}{l}0.05 \\
\text { Sig. }\end{array}$} \\
\hline & Experimental & 20 & 28.25 & 565.00 & & \\
\hline \multirow{2}{*}{$\begin{array}{l}\text { Listening to } \\
\text { the main idea }\end{array}$} & Control & 20 & 11.80 & 236.00 & \multirow{2}{*}{-5.001} & \multirow{2}{*}{$\begin{array}{l}0.05 \\
\text { Sig. }\end{array}$} \\
\hline & Experil & 20 & 29.20 & 584.00 & & \\
\hline \multirow{2}{*}{$\begin{array}{c}\text { Listening for } \\
\text { gist }\end{array}$} & Control & 20 & 12.53 & 250.50 & \multirow{2}{*}{-4.631} & 0.05 \\
\hline & Experimental & 20 & 28.48 & 569.50 & & Sig. \\
\hline \multirow{2}{*}{$\begin{array}{c}\text { Making } \\
\text { inferences }\end{array}$} & Control & 20 & 15.60 & 312.00 & \multirow{2}{*}{-3.392} & 0.05 \\
\hline & Experimental & 20 & 25.40 & 508.00 & & Sig. \\
\hline \multirow{2}{*}{$\begin{array}{c}\text { Listening for } \\
\text { details }\end{array}$} & Control & 20 & 11.70 & 234.00 & \multirow{2}{*}{-5.039} & \multirow{2}{*}{$\begin{array}{l}0.05 \\
\text { Sig. }\end{array}$} \\
\hline & Experimental & 20 & 29.30 & 586.00 & & \\
\hline \multirow{2}{*}{$\begin{array}{c}\text { Guessing } \\
\text { meaning from } \\
\text { context }\end{array}$} & Control & 20 & 16.00 & 320.00 & \multirow[b]{2}{*}{-2.902} & \multirow{2}{*}{$\begin{array}{l}0.05 \\
\text { Sig. }\end{array}$} \\
\hline & Experimental & 20 & 25.00 & 500.00 & & \\
\hline \multirow{2}{*}{$\begin{array}{c}\text { The whole } \\
\text { test }\end{array}$} & Control & 20 & 10.50 & 210.00 & \multirow{2}{*}{-5.438} & \multirow{2}{*}{$\begin{array}{l}0.05 \\
\text { Sig. }\end{array}$} \\
\hline & Experimental & 20 & 30.50 & 610.00 & & \\
\hline
\end{tabular}

The results shown in table (1) reveal that the mean scores of the control group on the post application of the listening test ranged from 10.50 to 12.53 whereas the means scores of the experimental group ranged from 25.00 to 30.00 . This indicates that the experimental group members outperformed their peers 
in the control group on the post application of the listening pre posttest due the webquest program.

A closer look at the table reveals that the highest mean scores of the control group were 16.00 in 'guessing meaning from context' and 15.60 on the subskill of 'making inferences'. On the other hand, the highest mean scores for the experimental group were 29.30 on the subskill of 'listening for details' and 29.20 on the subskill of 'listening to the main idea'. The lowest means scores of the experimental group were 25.00 and 25.40 on the subskills: making inferences and guessing meaning from context. In the middle there were some mean scores such as 28.78 for listening for specific information and 28.25 for extracting information. It is worth noting that these differences were significant at level 0.05 . This indicates that the webquest program was effective in boosting the subskills: listening to the main idea and listening for details more than the other subskills. In addition, the subskills: listening for specific information and extracting information both come in the second rank. On the other hand, the webquest program was not as effective as it was on 'making inferences' and 'guessing meaning from context'.

Based on this, it can be concluded that there were statistically significant differences between mean scores of the participants of the control group and the experimental group in the listening sub-skills and in the total mark of the test in favor of the experimental group as $\mathrm{z}$ and the $\eta 2$ values were high $(\eta 2=5.438)$ and statistically significant at the level $(0.05)$. These results prove that the first hypothesis was true.

\section{b- Comparison of the experimental group performance on the pre and the post applications of the listening test:}

In order to verify the effect size of the (WQP) in promoting the experimental group students' listening skill, the Wilcoxon Signed Ranks Test was used and the results of the test are shown in table (2): 
Table (2) Wilcoxon Signed Ranks Test results for difference in mean scores and $Z$ values of the experimental group on pre and post applications of the pre posttest of listening

\begin{tabular}{|c|c|c|c|c|c|c|c|c|}
\hline VARIABLES & Rank & \begin{tabular}{|l|}
$\begin{array}{l}\text { N. of } \\
\text { cases }\end{array}$ \\
\end{tabular} & $\begin{array}{l}\text { Mean } \\
\text { Rank }\end{array}$ & $\left|\begin{array}{l}\text { Sum of } \\
\text { Ranks }\end{array}\right|$ & \begin{tabular}{|c|} 
Z. \\
Value \\
\end{tabular} & Sig. & $\eta 2$ & $\begin{array}{c}\text { Effect } \\
\text { size }\end{array}$ \\
\hline \multirow{4}{*}{$\begin{array}{l}\text { 1- Listening } \\
\text { for specific } \\
\text { information }\end{array}$} & $\begin{array}{c}\text { Negative } \\
\text { Ranks }\end{array}$ & $\mathbf{0}$ & 0.00 & 0.00 & \multirow{4}{*}{3.097} & \multirow{4}{*}{$\begin{array}{c}0.05 \\
\text { Sig. }\end{array}$} & \multirow{4}{*}{$69.3 \%$} & \multirow{4}{*}{ High } \\
\hline & $\begin{array}{c}\text { Positive } \\
\text { Ranks }\end{array}$ & 12 & 6.50 & 78.00 & & & & \\
\hline & Ties & 8 & & & & & & \\
\hline & Total & 20 & & & & & & \\
\hline \multirow{4}{*}{$\begin{array}{c}2- \\
\text { Extracting } \\
\text { information } \\
\text { from } \\
\text { context }\end{array}$} & $\begin{array}{c}\text { Negative } \\
\text { Ranks }\end{array}$ & $\mathbf{0}$ & 0.00 & 0.00 & \multirow{4}{*}{3.391} & \multirow{4}{*}{$\begin{array}{l}0.05 \\
\text { Sig. }\end{array}$} & \multirow{4}{*}{$75.8 \%$} & \multirow{4}{*}{ High } \\
\hline & $\begin{array}{c}\text { Positive } \\
\text { Ranks }\end{array}$ & 14 & 7.50 & 105.00 & & & & \\
\hline & Ties & 6 & & & & & & \\
\hline & Total & 20 & & & & & & \\
\hline \multirow{4}{*}{$\begin{array}{l}\text { 3- listening } \\
\text { to get the } \\
\text { main idea }\end{array}$} & $\begin{array}{c}\text { Negative } \\
\text { Ranks }\end{array}$ & $\mathbf{0}$ & 0.00 & 0.00 & \multirow{4}{*}{3.241} & \multirow{4}{*}{$\begin{array}{l}0.05 \\
\text { Sig. }\end{array}$} & \multirow{4}{*}{$72.5 \%$} & \multirow{4}{*}{ High } \\
\hline & $\begin{array}{c}\text { Positive } \\
\text { Ranks }\end{array}$ & 13 & 7.00 & 91.00 & & & & \\
\hline & Ties & 7 & & & & & & \\
\hline & Total & 20 & & & & & & \\
\hline \multirow{4}{*}{$\begin{array}{l}\text { 4- Listening } \\
\text { for gist }\end{array}$} & $\begin{array}{c}\text { Negative } \\
\text { Ranks }\end{array}$ & $\mathbf{0}$ & 0.00 & 0.00 & \multirow{4}{*}{2.887} & \multirow{4}{*}{$\begin{array}{l}0.05 \\
\text { Sig. }\end{array}$} & \multirow{4}{*}{$64.6 \%$} & \multirow{4}{*}{ High } \\
\hline & $\begin{array}{c}\text { Positive } \\
\text { Ranks }\end{array}$ & 9 & 5.00 & 45.00 & & & & \\
\hline & Ties & 11 & & & & & & \\
\hline & Total & 20 & & & & & & \\
\hline \multirow{4}{*}{$\begin{array}{l}\text { 5-Making } \\
\text { inferences }\end{array}$} & $\begin{array}{c}\text { Negative } \\
\text { Ranks }\end{array}$ & $\mathbf{0}$ & 0.00 & 0.00 & \multirow{4}{*}{2.739} & \multirow{4}{*}{$\begin{array}{l}0.05 \\
\text { Sig. }\end{array}$} & \multirow{4}{*}{$61.2 \%$} & \multirow{4}{*}{ High } \\
\hline & $\begin{array}{c}\text { Positive } \\
\text { Ranks }\end{array}$ & 9 & 5.00 & 45.00 & & & & \\
\hline & Ties & 11 & & & & & & \\
\hline & Total & 20 & & & & & & \\
\hline \multirow{4}{*}{$\begin{array}{l}\text { 6- Listening } \\
\text { for } \\
\text { important } \\
\text { details }\end{array}$} & $\begin{array}{c}\text { Negative } \\
\text { Ranks }\end{array}$ & $\mathbf{0}$ & 0.00 & 0.00 & \multirow{4}{*}{3.571} & \multirow{4}{*}{$\begin{array}{l}0.05 \\
\text { Sig. }\end{array}$} & & \\
\hline & $\begin{array}{c}\text { Positive } \\
\text { Ranks }\end{array}$ & 15 & 8.00 & 120.00 & & & $79.8 \%$ & High \\
\hline & Ties & 5 & & & & & & \\
\hline & Total & 20 & & & & & & \\
\hline 7- Guessing & $\begin{array}{c}\text { Negative } \\
\text { Ranks }\end{array}$ & $\mathbf{0}$ & 0.00 & 0.00 & & & & \\
\hline $\begin{array}{c}\text { meaning } \\
\text { from }\end{array}$ & $\begin{array}{c}\text { Positive } \\
\text { Ranks }\end{array}$ & 7 & 4.00 & 28.00 & $2 . \overline{646} \mid$ & $\begin{array}{c}\text { 0.05 } \\
\text { Sig. }\end{array}$ & $59.2 \%$ & High \\
\hline & Ties & 13 & & & & & & \\
\hline & Total & 20 & & & & & & \\
\hline & $\begin{array}{c}\text { Negative } \\
\text { Ranks }\end{array}$ & 0 & 0.00 & 0.00 & & & & \\
\hline $\begin{array}{c}\text { The whole } \\
\text { test }\end{array}$ & $\begin{array}{c}\text { Positive } \\
\text { Ranks }\end{array}$ & 20 & 10.50 & 210.00 & 3.937 & $\begin{array}{l}0.05 \\
\text { Sig. }\end{array}$ & $88 \%$ & High \\
\hline & Ties & $\mathbf{0}$ & & & & & & \\
\hline & Total & 20 & & & & & & \\
\hline
\end{tabular}


The results in table (2) reveal that the mean score of the different listening subskills have been remarkably different. The highest mean scores of listening subskills were 8.00, 7.50 and 7.00 for 'listening for important details', 'extracting information from context' and 'listening to get the main idea' in order. So, they are the highest subskills developed by the webquest program. On the other hand, the mean scores for 'guessing the meaning from context', 'listening for gist' and 'making inferences' were the lowest:4.00, 5.00 and 5.00 in order. In the middle there was 'listening for specific information' as its mean score was 6.50. Increasingly, the $\mathrm{z}$ values ranged from 3.571 to 2.646 and were significantly different from one subskill to another. These results showed also that the effect size of the program on the whole test was significantly high at level 0.05 as the $\eta 2$ value was remarkably high $(\eta 2=3.937)$.

These results clarify that the webquest program was effective in boosting the target listening subskills as a whole and was more beneficial for some subskills: 'listening for important details', 'extracting information from context' and 'listening to get the main idea' than for others: 'guessing the meaning from context', 'listening for gist' and 'making inferences'. Hence, it can be concluded that there were statistically significant differences between the mean scores of the experimental group students on both the pre and post applications of the pre posttest of listening in favor of the post application of the test.

\section{Verifying the Speaking Skill Hypotheses:}

There are statistically significant differences between the mean scores of the students of the control and experimental groups on the post application of the speaking pre posttest.

To verify this hypothesis, the Mann-Whitney Test was used to calculate the difference in study groups performance on the post application of the speaking test. The results are presented in the following table (3): 
Table (3): $Z$ values and results of Mann-Whitney test of the mean scores of the experimental and control group in the post application of the pre posttest of speaking

\begin{tabular}{|c|c|c|c|c|c|c|}
\hline Listening Subskills & The group & \begin{tabular}{|c|}
$\begin{array}{l}N . \text { of } \\
\text { cases }\end{array}$ \\
\end{tabular} & $\begin{array}{l}\text { Mean } \\
\text { Rank }\end{array}$ & $\begin{array}{l}\text { Sum of } \\
\text { Ranks }\end{array}$ & \begin{tabular}{|c|} 
Z. \\
Value
\end{tabular} & Sig. \\
\hline \multirow{2}{*}{$\begin{array}{l}\text { Expressing a range } \\
\text { of functions to } \\
\text { satisfy social needs }\end{array}$} & $\mathrm{Co}$ & 20 & $\mathbf{1 1 . 5 0}$ & 230.00 & \multirow{2}{*}{5.094} & \multirow{2}{*}{$\begin{array}{c}0.05 \\
\text { Sig. }\end{array}$} \\
\hline & Exper & 20 & 29.50 & 590.00 & & \\
\hline \multirow{2}{*}{$\begin{array}{c}\text { Asking a range of } \\
\text { questions }\end{array}$} & Cor & 20 & 12.43 & 248.50 & \multirow{2}{*}{$4 . \overline{4}$} & \multirow{2}{*}{$\begin{array}{l}0.05 \\
\text { Sig. }\end{array}$} \\
\hline & Experi & 20 & 28.58 & 571.50 & & \\
\hline \multirow{2}{*}{$\begin{array}{l}\text { Giving a short } \\
\text { presentation on } \\
\text { familiar topics }\end{array}$} & Co & 20 & 11.88 & 237.50 & \multirow{2}{*}{$\begin{array}{c}- \\
4.972\end{array}$} & \multirow{2}{*}{$\begin{array}{l}0.05 \\
\text { Sig. }\end{array}$} \\
\hline & Exper & 20 & 29.13 & 582.50 & & \\
\hline \multirow{2}{*}{$\begin{array}{c}\text { Expressing ideas on } \\
\text { everyday topics }\end{array}$} & & 20 & 13.05 & 261.00 & \multirow{2}{*}{4.271} & \multirow{2}{*}{$\begin{array}{l}0.05 \\
\text { Sig. }\end{array}$} \\
\hline & Expe & 20 & 27.95 & 559.00 & & \\
\hline \multirow{2}{*}{$\begin{array}{c}\text { Using grammatical } \\
\text { structures in } \\
\text { utterances } \\
\text { accurately }\end{array}$} & & 20 & 11.33 & 226.50 & \multirow[b]{2}{*}{$5 . \overline{-}$} & \multirow[b]{2}{*}{$\begin{array}{l}0.05 \\
\text { Sig. }\end{array}$} \\
\hline & Experim & 20 & 29.68 & 593.50 & & \\
\hline \multirow{2}{*}{$\begin{array}{l}\text { Producing the } \\
\text { English sounds } \\
\text { correctly }\end{array}$} & & 20 & 12.38 & 247.50 & \multirow{2}{*}{4.} & \multirow{2}{*}{$\begin{array}{l}0.05 \\
\text { Sig. }\end{array}$} \\
\hline & Expe & 20 & 28.63 & $\mathbf{5 7 2 . 5 0}$ & & \\
\hline \multirow{2}{*}{$\begin{array}{c}\text { Using new } \\
\text { vocabulary items } \\
\text { appropriately }\end{array}$} & & 20 & 12.60 & 252.00 & \multirow{2}{*}{$4 . \overline{-}$} & \multirow{2}{*}{$\begin{array}{l}0.05 \\
\text { Sig. }\end{array}$} \\
\hline & Exper & 20 & 28.40 & 568.00 & & \\
\hline \multirow{2}{*}{$\begin{array}{c}\text { Narrating incidents } \\
\text { or events in a logical } \\
\text { sequence }\end{array}$} & Co & 20 & 12.78 & 255.50 & \multirow{2}{*}{$4 . \overline{561}$} & \multirow{2}{*}{$\begin{array}{l}0.05 \\
\text { Sig. }\end{array}$} \\
\hline & ExperimeI & 20 & 28.23 & 564.50 & & \\
\hline \multirow{2}{*}{ All Test } & Co & 20 & 10.53 & 210.50 & \multirow{2}{*}{$5 . \overline{-}$} & \multirow{2}{*}{$\begin{array}{l}0.05 \\
\text { Sig. }\end{array}$} \\
\hline & Experi & 20 & 30.48 & 609.50 & & \\
\hline
\end{tabular}

The results shown in table (3) reveal that the mean scores of the control group on the post application of the listening test ranged from 11.33 to 12.78 whereas the means scores of the experimental group ranged from 27.95 to 29.68. This indicates that the experimental group members outperformed their peers in the control group on the post application of the speaking pre posttest due the webquest program.

A closer look at the table reveals that the highest mean scores of the control group on some speaking subskills such as 13.05 for 'expressing ideas on everyday topics' subskill while the lowest mean score for this group was 11.50. for the experimental group and due to the high effect of the webquest-based program, 
the mean scores were high and differed among the different subskills. For example, the highest means scores were for the subskills: using grammatical structures in utterances accurately' and ' expressing a range of functions to satisfy social needs'. In the middle, the means score of 'using new vocabulary appropriately' was 28.40 and the mean score of 'asking a range of questions reached 28.85. The lowest mean scores were those of 'expressing ideas on everyday topics' subskill which was 27.95 .

The results shown on table 3 also show that $\mathrm{z}$ value and the effect size of the webquest-based program on the overall test of speaking was remarkably high as the $\eta 2$ was remarkably high $(\eta 2=5.421)$ that means significance at level of 0.05 . These results proved that the first hypothesis was true.

According to the findings shown in table (3), there are statistically significant differences between the mean scores of the students of the study groups in the different subskills of the pre posttest of speaking and in their final marks on the test in favor of the experimental group students' scores on the post application of the test because they got the highest mean score and $z$ value was high $(\eta 2=5.421)$ and was significant at the level 0.05 . Thus, this hypothesis has been proved to be true.

\section{b. Verifying the second hypothesis of speaking:}

There are statistically significant differences between the mean scores of students in the experimental group's performance on the pre application of the speaking test and their performance on the post application in favor of the post application.

To verify this hypothesis, the Wilcoxon Signed Ranks Test was used to calculate the difference between the experimental group performance on the pre and that on the post application of the speaking test. The results are presented here in table (4) as follows: 
Tabl(4): Wilcoxon Signed Ranks Test results of exp. Gr. Performance on the post application of speaking test

\begin{tabular}{|c|c|c|c|c|c|c|c|c|}
\hline \begin{tabular}{|c|}
$\begin{array}{c}\text { Speaking sub } \\
\text { skills }\end{array}$ \\
\end{tabular} & Rank & $\begin{array}{l}\text { N. of } \\
\text { cases }\end{array}$ & $\begin{array}{l}\text { Mean } \\
\text { Rank } \\
\end{array}$ & \begin{tabular}{|c|} 
Sum of \\
Ranks \\
\end{tabular} & \begin{tabular}{|c|}
$\mathrm{Z}$. \\
Value \\
\end{tabular} & Sig. & $\eta 2$ & $\begin{array}{c}\text { Effect } \\
\text { size }\end{array}$ \\
\hline \multirow{4}{*}{\begin{tabular}{|c|} 
Expressing a \\
range of \\
functions to \\
satisfy social \\
needs \\
\end{tabular}} & Negative Ranks & $\mathbf{0}$ & 0.00 & 0.00 & \multirow{4}{*}{$3 . \overline{835}$} & \multirow{4}{*}{$\begin{array}{l}0.05 \\
\text { Sig. }\end{array}$} & \multirow{4}{*}{$85.8 \%$} & \multirow{4}{*}{ High } \\
\hline & \begin{tabular}{|l|} 
Positive Ranks \\
\end{tabular} & 18 & 9.50 & 171.00 & & & & \\
\hline & Ties & 2 & & & & & & \\
\hline & Total & 20 & & & & & & \\
\hline \multirow{4}{*}{$\begin{array}{c}\text { Asking a } \\
\text { range of } \\
\text { questions }\end{array}$} & \begin{tabular}{|l|} 
Negative Ranks \\
\end{tabular} & $\mathbf{0}$ & 0.00 & 0.00 & \multirow{4}{*}{$3 . \overline{601}$} & \multirow{4}{*}{$\begin{array}{l}0.05 \\
\text { Sig. }\end{array}$} & \multirow{4}{*}{$80.5 \%$} & \multirow{4}{*}{ High } \\
\hline & \begin{tabular}{|l|} 
Positive Ranks \\
\end{tabular} & 16 & 8.50 & 136.00 & & & & \\
\hline & Ties & 4 & & & & & & \\
\hline & Total & 20 & & & & & & \\
\hline \multirow{4}{*}{\begin{tabular}{|c|} 
Giving a \\
short \\
presentation \\
on familiar \\
topics \\
\end{tabular}} & \begin{tabular}{|l|} 
Negative Ranks \\
\end{tabular} & $\mathbf{0}$ & 0.00 & 0.00 & \multirow{4}{*}{$\begin{array}{c}- \\
3.598\end{array}$} & \multirow{4}{*}{$\begin{array}{l}0.05 \\
\text { Sig. }\end{array}$} & \multirow{4}{*}{$80.5 \%$} & \multirow{4}{*}{ High } \\
\hline & \begin{tabular}{|l|} 
Positive Ranks \\
\end{tabular} & 16 & 8.50 & 136.00 & & & & \\
\hline & Ties & 4 & & & & & & \\
\hline & Total & 20 & & & & & & \\
\hline \multirow{4}{*}{$\begin{array}{c}\text { Expressing } \\
\text { ideas on } \\
\text { everyday } \\
\text { topics }\end{array}$} & Negative Ranks & $\mathbf{0}$ & 0.00 & 0.00 & \multirow{4}{*}{3.841} & \multirow{4}{*}{$\begin{array}{c}0.05 \\
\text { Sig. }\end{array}$} & \multirow{4}{*}{$85.9 \%$} & \multirow{4}{*}{ High } \\
\hline & \begin{tabular}{|l|} 
Positive Ranks \\
\end{tabular} & 18 & 9.50 & 171.00 & & & & \\
\hline & Ties & 2 & & & & & & \\
\hline & Total & 20 & & & & & & \\
\hline \multirow{4}{*}{\begin{tabular}{|c|} 
Using \\
grammatical \\
structures in \\
utterances \\
accurately \\
\end{tabular}} & \begin{tabular}{|l|} 
Negative Ranks \\
\end{tabular} & $\mathbf{0}$ & 0.00 & 0.00 & \multirow{4}{*}{$-\overline{-}$} & \multirow{4}{*}{$\begin{array}{l}0.05 \\
\text { Sig. }\end{array}$} & \multirow{4}{*}{$85.7 \%$} & \multirow{4}{*}{ High } \\
\hline & \begin{tabular}{|l|} 
Positive Ranks \\
\end{tabular} & 18 & 9.50 & 171.00 & & & & \\
\hline & Ties & 2 & & & & & & \\
\hline & Total & 20 & & & & & & \\
\hline \multirow{4}{*}{$\begin{array}{l}\text { Producing } \\
\text { the English } \\
\text { sounds } \\
\text { correctly } \\
\end{array}$} & \begin{tabular}{|l} 
Negative Ranks \\
\end{tabular} & $\mathbf{0}$ & 0.00 & 0.00 & & & & \\
\hline & \begin{tabular}{|l|} 
Positive Ranks \\
\end{tabular} & 15 & 8.00 & 120.00 & - & 0.05 & & \\
\hline & Ties & 5 & & & 3.571 & Sig. & $\%$ & High \\
\hline & Total & 20 & & & & & & \\
\hline Using new & Negative Ranks & $\mathbf{0}$ & 0.00 & 0.00 & & & & \\
\hline vocabulary & \begin{tabular}{|l|} 
Positive Ranks \\
\end{tabular} & 18 & 9.50 & 171.00 & & & & \\
\hline items & Ties & 2 & & & 3.943 & Sig. & $88.2 \%$ & High \\
\hline $\begin{array}{c}\text { approprtater } \\
\text { y } \\
\end{array}$ & Total & 20 & & & & & & \\
\hline Narrating & \begin{tabular}{|l|} 
Negative Ranks \\
\end{tabular} & $\mathbf{0}$ & 0.00 & 0.00 & & & & \\
\hline incidents or & \begin{tabular}{|l|} 
Positive Ranks \\
\end{tabular} & 16 & 8.50 & 136.00 & & & & \\
\hline events in a & Ties & 4 & & & 3.656 & Sig. & $81.8 \%$ & High \\
\hline $\begin{array}{c}\text { logical } \\
\text { sequence }\end{array}$ & Total & 20 & & & & & & \\
\hline & \begin{tabular}{|l|} 
Negative Ranks \\
\end{tabular} & $\mathbf{0}$ & 0.00 & 0.00 & & & & \\
\hline $\mathrm{Al}$ & \begin{tabular}{|l} 
Positive Ranks \\
\end{tabular} & 20 & 10.50 & 210.00 & - & 0.05 & & \\
\hline AII TESt & Ties & $\mathbf{0}$ & & & 3.928 & Sig. & $37.8 \%$ & High \\
\hline & Total & 20 & & & & & & \\
\hline
\end{tabular}

A closer look at table 4 reveals that A closer look at table 4 reveals that the mean scores of the different speaking subskills were remarkably high. The mean scores were 9.50 for 
'expressing a range of functions to satisfy social needs', 'expressing ideas on everyday topics', 'using grammatical structures in utterances accurately', and 'using vocabulary items appropriately'. Moreover, the mean scores of the rest of speaking subskills was 8.00 and 8.50 which are considered high as well. Increasingly the $\mathrm{z}$ value and the effect size of the webquest program was high $(\eta 2=87.8 \%)$. This indicates that the webquest program was effective in enhancing the speaking subskills of the students' in the experimental group. The results shown in table 4 indicate that there were statistically significant differences between students of the experimental group on the post and pre application of the speaking test in favor of the post application.

\section{Discussion of Results:}

Based on statistical results represented in tables 1, 2, 3 and 4 , the present study reveal that the webquest program was effective and helped secondary stage students develop their EFL listening and speaking skills.

In addition to the positive effect of the WQP shown by quantitative statistical results, there have been positive attitudes and qualitative data through the researcher's own observations and notes that proved the effectiveness of the WQP, too. For example, some participants expressed their positive attitudes towards the webquest. Here are some of their comments:

1. 'Webquest is a user-friendly tool. It is easy to use.'

2. 'I'd like to be taught by webquest even in other subjects.'

3. 'Webquest helped me interact with my classmates.'

4. 'It taught me how to start a conversation and end it. I was unable even to talk in English in public.'

5. 'It helped me broaden my computer information and work on office.'

6. 'I have learnt how to do research on the Internet.'

These results are congruent with the results of previous studies in the field of EFL/ESL (Tsai, 2005; Chuo, 2007; Siko, 2008; Pulido, 2009; Mostafa, 2009; Almasri et al, 2011; 
Alshummaimeri, 2012; ElKhateeb, 2012; Shan, 2011; Termsinsawadi, 2011; Tuan, 2011; Valesco, 2012; Alshummaimeri \& Bamanger, 2013) and the study results are also congruent with the previous studies that investigated webquest and speaking skill (Laborda, 2009; Laborda, 2010) and with the studies which investigated webquests and selfregulation (Lara \& Reparaz, 2007; Odom, 2008; Gowen, 2010; Hsaio et al, 2012). The results are also in agreement with English \& Kitsantas (2013) who discussed the students' self-regulated learning in a project-based learning and Li \& Yue (2011) who investigated a webquest metacognitive speaking strategy.

The findings of this study are also congruent with Sullivan and Pratt (1996) and Chuo (2007) who found, in comparative studies, web based learning environment classes exhibited significant gains in writing. Chuo (2007) argued that the quality of the input that the WebQuest gives the learners is the reason behind this significant improvement in the students' performance (Quoted in AlShumaimeri \& Bamanger, 2012).

These positive findings and significant differences between the control and experimental group were due to the efficiency of the WQBP. The proposed webquest program had certain features that helped the experimental group do well on the post application of the pre -posttests of listening and speaking. First, using peer-learning helps learners to correct each other's mistakes by exchanging their own information. Second, the researcher's continuous direction to students during their work. The researcher used to guide them, correct them, and assess their work. This direction helps students' see their own right. Third, using the webquest as a teaching technique for the first time in Egypt and the Middle East to teach listening and speaking skills was a big challenge for the researcher. According to literature, Webquest used to be used in teaching reading and writing skills. Moreover, using the webquest made students depend on themselves and cooperate together in addition to being aware of what they should do during their learning. They have known how to set a goal for their learning and how they can 
achieve it. Additionally, using pair work and group work proved to be vital in doing their own tasks well. Finally, the nontraditional role of the teacher during the program made the learning process supporting and interesting. The teacher or the researcher was a guide, a helped, a mentor and a supervisor in addition to Using the students the reflection log to assess or evaluate themselves made them dependent and self-confident.

\section{Conclusions:}

Based on the results of the study, the following conclusions were reached:

1. The experimental group students outperformed the control group students in listening posttest at the level (0.05) level.

2. The experimental group students outperformed the control group students in speaking posttest at the level (0.05) level.

3. The experimental group students performed better on the post application of the SRQ.

\section{Recommendations of the Study:}

Based on the results of the study, the following recommendations should be taken into consideration when teaching EFL:

1. The proposed webquest program can be adopted by secondary school teachers for teaching English in general ad listening and speaking skills in particular.

2. Teachers should use multiple teaching strategies and resources that can cope with students' needs and learning styles.

3. It is necessary to devote more time to teaching listening and speaking.

4. Reflection logs should be activated inside classrooms to give students an opportunity to assess themselves and their own learning or their peers'.

5. SRL is a critical skill for student success in PBL. The lack of such skills poses an obstacle to learning. While teachers 
may agree that they need to support students' development of SRL, research has shown that many do not know how to do so. Therefore, there should be benefit from including training and education on SRL development as an integral part of pre-service and professional development activities (English \& Kitsantas, 2013).

6. Cooperative learning, peer learning, group work and pair work should all be activated inside the EFL classroom

7. Teachers should devote some time for teaching students how to give an oral presentation and/or peer-interview

8. Teachers should manipulate techniques that can encourage students to connect prior knowledge with new knowledge, such as scaffolding learning, and experiential learning.

9. Students have different learning styles that should be taken into consideration when planning for teaching. This is one the main principles of constructivism that makes students the center of the learning/teaching process.

10. Incorporating webquest teaching technique in teacher preparation and professional development courses.

\section{References}

Abdelal, A. (2002). "The Effect of a Strategy-Based Instruction Program on Developing EFL Listening Comprehension Skills," A PhD Dissertation, Center for English Language Teacher Education, University of Warwick, UK.

Abdelatif, M. (2012). "Teaching a Standards-Based Communicative English Textbook Series to Secondary School Students in Egypt: Investigating Teachers' Practices and Beliefs," English Teaching: Practice \& Critique, Sept. 2012, Vol. 11, No. 3, pp. 78 - 97.

Alshumaimeri, Y.; Alfadda, H.; Almasri, M. (2011) "A Preliminary Study of the Effect of WebQuests on the Writing Performance of Saudi Female EFL Elementary School Students," JALTCALL Journal, 7(3), 373 - 390. 
Al-Shummaimeri, Y. \& Almasri, M. (2012) "The Effects of Using WebQuests on Reading Comprehension Performance of Saudi EFL Students," The Turkish Online Journal of Educational Technology, Oct. 2012, 11(4), 295-306.

Al-Shummaimeri, Y. \& Bamanger, E. (2013) "The Effects of WebQuest Writing Instruction on the Writing Performance of Saudi Male EFL Learners, Procedia Social and Behavioral Sciences, 83, 960-968.

Barani, G. (2011). The Relationship between Computer Assisted Language Learning (CALL) and Listening Skill of Iranian EFL Learners. Procedia Social and Behavioral Sciences 15, 4059-4063.

Beall, M.; Gill-Rosier, J.; Tate, J.; Matten, A. (2008). State of the Context: Listening in Education. The International Journal of Listening, 22, $123-132$.

Cigrik, E. \& Ergul, R. (2010). The investion effect of using webquest on logical thinking ability in science education. Procedia social and behavioral sciences2, 4918-4922.

Dodge, B. (1997). "Some thought about WebQuests", Retrieved at 29/09/2013, from San Diego State University: http://Web Quest.sdsu.edu/about_WebQuests.html

Dodge, B. (2001). "Five rules for writing a great WebQuest," Learning \& Leading with Technology, vol. 28, pp. 58-58.

Elkhateeb, E. (2012). The Impact of Using WebQuests on the Palestinian Seventh Graders' English Reading Comprehension Skills and their Attitudes Towards WebQuest," An Unpublished MA Thesis, Faculty of Education, the Islamic University of Gaza Strip, Palestine.

Fatemi, M.; AliShahi, M.; Khorasani, M.; and Seifi, M. (2014) The Relationship between EFL learners' self-regulation and their listening comprehension. Advances in language and literary studies, 5, 4, Doi:10.757/aiac.alls.v.5n.4p.198.

Florez, M. C. (1999). Improving Adult English Language Learners' Speaking Skills. ERIC Digest, ERIC Document Reproduction Service, No. ED: 435204.

Hamouda, A. (2013). An Investigation of Listening Comprehension Problems Encountered by Saudi Students 
in the EL Listening Classroom," International Journal of Academic Research in Progressive Education and Development, April, Vol. 2, No. 2, pp. 113 - 155.

Hsiao, H.; Tsai, C.; Lin, C-Y; Lin, C.Y. (2012). "Implementing A Self-

Regulated WebQuest Learning System for Chinese

Elementary Schools," Australian Journal of Educational

Technology, 28(2), 315 - 340.

Koçak, M. (2010). A Novice Teacher's Action Research on EFL

Learner's Speaking Anxiety. Procedia Social and Behavioral

Sciences, 3, $138-143$.

Koçoglu, Z. (2010) "WebQuests in EFL Reading/Writing Classroom," Procedia Social and Behavioral Sciences 2, 3524-3527.

Laborda, J. (2009) "Using WebQuests for Oral Communication in EFL for Tourism Studies," Educational Technology and Society, 12(1), 258-270.

Laborda, J. (2010) "Fostering Face to Face Oral interaction through WebQuests: A Case Study in ESP for Tourism," Trab. Ling. Aplic., Campinas, 49(1), 275-292.

McCullers, C. A. (2005). The Influence of WebQuests on the Academic Achievements of Students in the Geometry Setting at Eastside High School. Instructional Technology Monographs 2, Retrieved on 10/11/2013 at: Http://itm.coe.uga.edu/archieves/spring2005/mcculler s.htm

Mostafa, A. (2009). "Integrating Internet Resources into EFL Curricula Using the WebQuest to Enhance Graduate Students' Reading and Writing Skills for Research Purposes," Paper Presented at the 2nd International Conference of Education, Research and Innovation, Madrid, Spain, 16-18 November, 2009.

Noordin, N.; Smaad, A. and Mohammed Razali A. (2008) "ESL Teacher Trainee Reflections on the Use of WebQuest: Practical or Just a Hype?" The English Teacher, XXXVI, University of Putra Malaysia, 66-80.

Oprandy, R. (1994) listening/Speaking in second and foreign language teaching, System, 22, 2, 153-175. 
Oxford, R. (1993). "Research update on teaching L2 listening. System, 21(2), pp. 205 -211.

Perkins, R. \& McKnight, M. (2005) Teachers' Attitudes toward WebQuests as a Method of Teaching". Computers in the Schools, 22, 1/2, 123-133.

Puthikanon, N. (2009) "Examining Critical Thinking and Language Use through the Use of WebQuests in an EFL Reading Class," a PhD Dissertation, Indiana University, USA.

Rivers, W. (1981). Teaching Foreign Language Skills. $2^{\text {nd }}$ edition, ERIC, Washington, USA.

Schweizer, H. \& Kossow, B. (2007). "WebQuests: Tools for Differentiation," Gifted Child Today, 30, 1, 29 - 35.

Sen, A. \& Neufeld, S. (2006). "In pursuit of Alternatives in ELT Methodology: WebQuests," The Turkish Online Journal of Educational Technology - TOJET, 5(1), 49-67.

Siegel, J. (2014). Exploring L2 Listening Instruction: examinations of practice. ELT Journal, 68 (1), 22 - 30.

Shan, C. (2011). "Using WebQuests to Facilitate Task-Based English Reading Instruction for Graduate Students," Chinese Journal of Applied Linguistics (Quarterly), vol. 34, No. 2, pp. 34-43.

Siko, K. (2008). "WebQuests in the EFL Classroom: How do they Affect Students' Learning," a $\mathrm{PhD}$ dissertation, the University of North Carolina at Chapel Hill, USA.

Solcova, P. (2011). Teaching Speaking Skills. An Unpublished MA thesis, Faculty of Arts, Masaryk University, Czech Republic.

Stannard, R. (2009). Hello English for Secondary Schools: Year Two. Teacher's guide. Egyptian Publishing Company, Longman, Cairo.

Termsinsawadi, P. (2011). WebQuest Module Development for Enhancing EFL Reading and Writing Abilities of Thai Undergraduate Engineering Students. Retrieved at: http://www.culi.chula.ac.th/e-journal/2011/pornpilai.pdf. Torky, S. (2006). "The Effectiveness of a Task-Based Instruction Program in Developing the English Language Speaking Skills of Secondary Stage Students." an Unpublished $\mathrm{PhD}$ 
Dissertation, Women's College, Ain Shams University, Cairo, Egypt.

Tsai, S.H. (2006b). Integrating WebQuest Learning into EFL Instruction. In C. Crawford et al. (Eds.), Proceedings of Society for Information Technology \& Teacher Education International Conference 2006 (pp. 2061-2067). Chesapeake, VA: AACE.

Tuan, L. (2011) "Teaching Reading through WebQuest," Journal of Language Teaching and Research, Vol. 2, No. 3, pp. 664 673.

Unal, Z.; Bodur, Y., \& Unal, A. (2012). Choosing or designing the perfect WebQuest for your learners using a reliable rubric. Contemporary Issues in Technology and Teacher Education, 12(2), 209-231.

Velasco, F. (2012). The Effect of WebQuests on Lexical Richness. An MA Dissertation, University of Groningen, Netherlands.

Vidoni, K.; Maddux, C. (2002) " WebQuests: Can they be used to improve Critical Thinking Skills in Students?" Computers in the Schools, vol. 19 (1/2), pp. $101-117$.

Wei, L. (2006). "Teaching Listening in EFL Classroom in Senior High Schools in Taiwan," retrieved on 10 - 10 - 2013. at: http://english.tyhs.edu.tw

Willis, J. (1996). A Framework for Task-Based Learning. Addison Wesley: Longman.

Yang, Y; Chuang, Y.; Li, L.; Tseng, S. (2013). "A Blended Learning Environment for Individualized English Listening and Speaking Integrating Critical Thinking," Computers and Education, 63, 285 - 305.

Yousif, A. (2006). Listening Comprehension Difficulties as Perceived by. Journal of King Saud University: language \& Translation, Vol. 19, pp. 35 - 47. 
